\title{
Immigration and Integration of Immigrants: Impacts of Research for Social and Security Policies
}

Dragana Avramov ${ }^{1}$

This article is based upon a presentation delivered at the $3^{\text {rd }}$ International Academic Conference on Human Security, Belgrade, organized by the Human Security Research Center (Faculty of Security Studies, University of Belgrade), 4-5 November 2016.

In recent years, there have been a plethora of conferences, expert groups, and stakeholder workshops addressing what some refer to as 'new migration'. These events are meant to provide the knowledge base for underpinning the updated European Agenda on Migration and the European Agenda on Security, and respective recommendations, directives, legislative documents, proposals, and action plans. ${ }^{2}$

In this article, we first address two questions: is there anything strikingly new in the ongoing immigration flows, and has there been lack of research to support policy choices or is it the case of the low take-up of research findings to redress the deficit of effective policies?

1 Dr Dragana Avramov, Population and Social Policy Consultants (PSPC), avramov@avramov.org

2 See, for example: https://ec.europa.eu/home-affairs/whatwe-do/policies/european-agenda-migration/backgroundinformation_en Brussels, with legislative documents, fact sheets, press material, and in particular 13 May 2015 COM (2015) 240 final Communication from the Commission to the European Parliament, the Council, the European Economic and Social Committee and the Committee of the Regions a European Agenda on Migration. 
Regarding security aspects, we argue that the impact of excessive social inequalities is a challenge for security and that badly integrated persons, of migrant and autochthones background, are both casualties and security hazards. Badly integrated immigrants having insufficient skills to be competitive in the labor market and not having appropriated the core values and norms of the host country fall victim to segregation and auto-segregation/ communitarianism. The weight of non-formal communitybased networks and parallel community structures built over years by violent movements has blatantly become evident to policy makers and lay people following the Paris attacks on 13 November 2015 and Brussels Bombing on 22 March 2016.

On the basis of the analysis of the driving forces and (lack of) management of immigration in Europe, we advance some reflections about immediate and longerterm forward-looking immigration and integration policy choices.

\section{Migration challenges in Europe}

Two key challenges may be identified. On the one hand, there is need for crisis management, in particular managing the refugee crisis (involving border management, saving lives, targeting criminal smuggling networks, relocation), and managing the asylum system (involving standards, the monitoring process, infringement procedures, 'asylum shopping'/abuses); on the other hand, foresight is necessary for attracting workers with the skills European countries need.

In determining what is new, we will briefly look at demography (namely the driving forces and Europe's needs for immigrants), the policy responses (taking into account the acceptance of immigrants in Europe, and integration of immigrants), and social impacts (involving selective legal immigration based on individual characteristics of candidate immigrants, and technology for controlling borders and tracking irregular migrants and ensuring their safe return). 


\section{European Human}

\section{Driving forces embedded in demography}

The key migration driving forces are embedded in demography (population growth), lack of security (wars, natural and man-made disasters), and pursuit of better opportunities (creating and sharing the distribution of abundance). These driving forces have remained largely unchanged for the present human since our ancestors hominines migrated from Africa some 90,000 years ago. Cliquet and Avramov (2017) discuss extensively the evolutionary heritage and modern changes in our drives for status achievement, egalitarianism, and avoidance of deprivation.

Of course, migration routes change - but evolution science tells us that humans are opportunists. We seize every opportunity to improve things for ourselves and for our offspring. So obviously we look at new routes. Also, the volume changes according to circumstances, as does the composition of the migrant populations. The question here is if we can anticipate change.

Figure 1 shows that in Africa, for example, growing numbers of young people needing education and wanting a good life are foreseeable and have been foreseen.

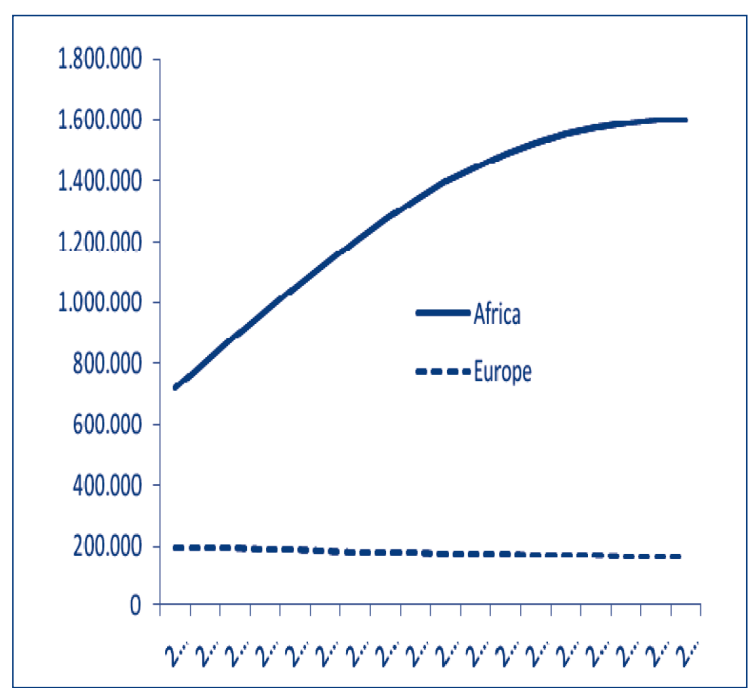

Figure 1: Population growth: age group 0-24 in Europe and Africa between 2015 and 2100 (United Nations Population Division, 2017). 
Figure 1 also shows that in Europe (data include the Russian Federation) the number of young people who will be entering education and the workforce is on a slow path to decline. It is reasonable to assume that young people from Africa will strive to access the level of abundance and security that their European counterparts enjoy.

The data for individual countries are even more revealing about the demographic driving forces from less developed economies to more prosperous countries.

In the period from 2010 to 2015 , the total population of Austria stood at 8.4 million and the fertility rate was 1.35. Ethiopia had the total of 83 million inhabitants and the fertility rate of 3.85 .

Since most people who will be having children and growing old in the next three decades or so are already born, it does not take much effort or too sophisticated skills to illustrate the probable future (United Nations Population Division, 2017). As a result of fertility dynamics, in 2050, the total population of Austria will remain largely unchanged (providing there is a fertility increase to 1.74), while that of Ethiopia will grow to 140 million (providing fertility drops to 1.87).

Population growth figures are only one part of the demographic landscape. The age structure shows very different population needs, with Austria facing significant shares of its population in transition to retirement, and Ethiopia significant shares of children and adolescents in transition to schooling and work. The shares of youth in transition to adulthood will be increasing in Ethiopia to levels that the economy may not be able to integrate.

Indeed, the age pyramids for Austria and Ethiopia (Figure 2) are a remarkable example of the long-term perspective that is foreseeable and foreseen. Demography informs policies and is integrated in policy narratives of various ideological colors. However, it is rarely taken into consideration for effectively changing policies. In most circles, demography is often presented as 'our destiny'. 


\section{European Human
Journal of Security}

Figure 2: Age groups in Austria and Ethiopia in 2050 (United Nations Population Division, 2017)

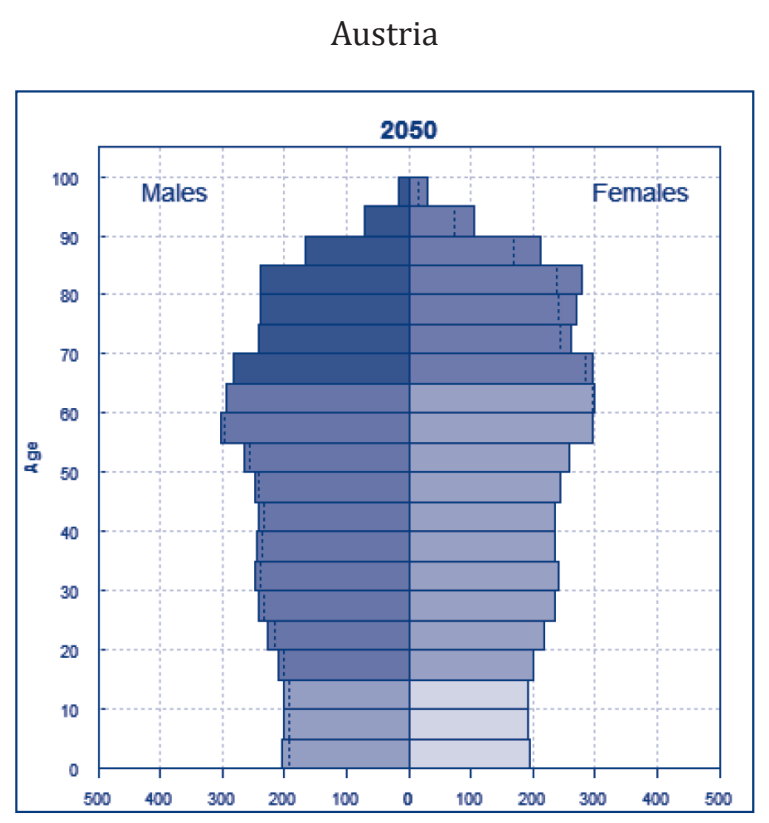

43 I Page

Ethiopia

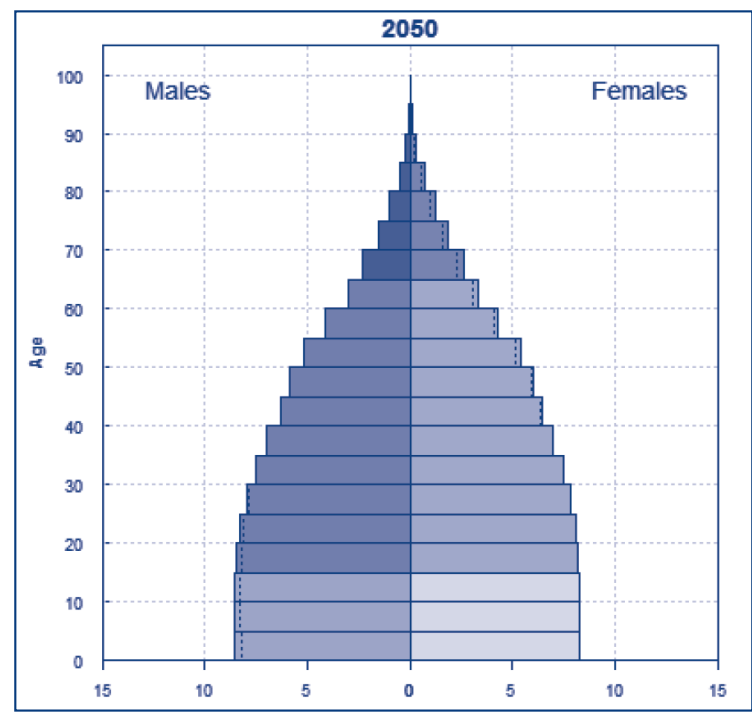

Issue 1 / 2017 
In Europe, the population decline was foreseen as early as the 1970s, when fertility started to decline. Foreseen several decades ago, the decrease in the size of Europe's population is expected to occur as of 2025. Population decline is also expected in more developed countries such as Japan, North America, Australia, and New Zealand. By contrast, in least developed countries, ${ }^{3}$ the population growth up to 2100 will be quite remarkable (Figure 3).

Figure 3: Population growth up to 2100: Europe, more developed countries, least developed countries (United Nations Populations Division, 2017)

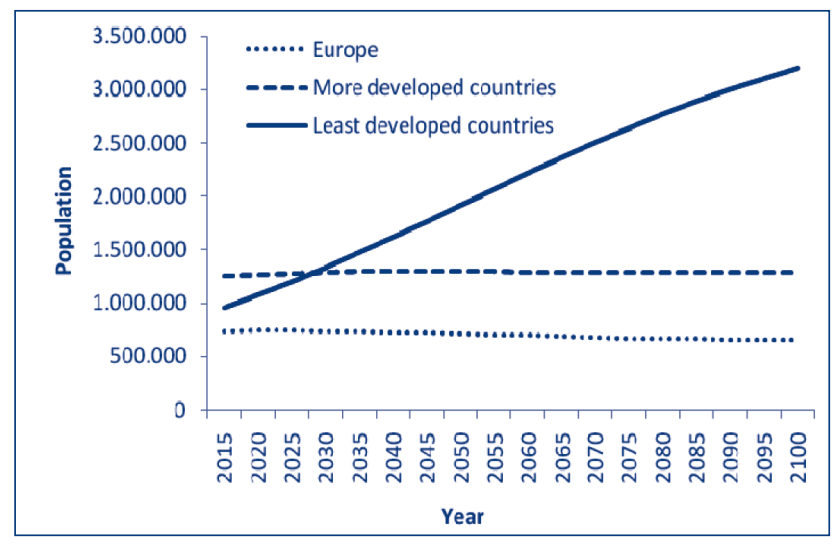

\section{What does demography tell us about human security?}

At least three conclusions may be drawn from a glance at the current demography and expected demographic future. Demography reveals that inequalities in life chances between populations in different countries and regions of the world, and between generations, will persist (the same as today, but more so). It signals that certain forms of population pressure, particularly youth

3 Least developed countries include: East Africa (Kenya, Zimbabwe); middle Africa (Cameroon, Congo, Gabon); Sudan; Lesotho; West Africa (Cape Verde, Côte d'Ivoire, Ghana, Nigeria); South Asia (Afghanistan, Bangladesh, Bhutan, Nepal); S.E. Asia (Cambodia, Lao, Timor); Yemen; Haiti; Solomon Islands; Vanuatu; Samoa; Tuvalu; Kiribati. 


\section{European Human}

bulges, may entail a higher risk for intrastate conflict. It shows that we may expect further increase in the diversity of potential immigrants according to country of origin, language, religion and other philosophical orientations.

We know from research that the most difficult situations emerge when high numbers of immigrants, large ethnic distance and strong inter-group competition coincide. Demography, furthermore, points in the direction of the conclusion that we need to manage our ecological footprint, ${ }^{4}$ as the ecological sustainability of our planetary environment is a prerequisite of human security. The ecological overshoot is already estimated at 1.5. If developing countries had a similar level of prosperity today as the developed ones, humans would be using the equivalent of nine Earths to support their consumption (Ewing et al., 2010, Wackernagel \& Rees, 1996).

The 'ecological footprint' is perhaps not a completely satisfactory instrument to measure the total ecological impact of humanity but it is an impressive and most elaborated proxy for measuring the human impact on the environment that sustains life as we know it.

Of course, demography operates in conjunction with other 'push factors'. There is nothing new in the link between regime change, uprisings, wars, natural disasters and mass population displacements. Immigration pressure into prosperous and easily accessible Europe could hardly have been a surprise.

4 Global Footprint Network's core research calculates both the Biocapacity (BC) and the Ecological Footprint (EF) for more than 200 countries, using over 5,000 data points for each country per year, derived from internationally recognized sources; these have been used to determine the area required to produce the biological resources a country uses and to absorb its wastes and to compare this with the area available. The ratio EF/BC is the estimated ecological overshoot. For 2007, the ecological overshoot (EF/BC) is 50 per cent above unity, meaning humanity used the equivalent of 1.5 Earths to support its consumption. 


\section{European Human \\ Journal of Security}

\section{Managing the work environment}

In Europe and in many developed economies worldwide, there are conflicting narratives as to the possible choices regarding managing work landscape and/or managing immigration.

In a global world, context changes in numbers and shares of the working age population (15 to 59 years of age) are a pretty good indicator of the foreseeable and foreseen expected pressure on the labor market.

The expected decline in the size of the working age population is visible in Europe and remarkable in China, as may be seen in Figure 4.

Regarding Europe, some plausible hypotheses may be advanced. Population ageing in Europe is a strong pressure factor for structural changes to the ways our societies are organized, to the shaping of the life course of individuals, and to the values attached to inter-generational solidarity (see Council of Europe, Perspectives on Youth, 2016).

Employers may need to be more flexible about how and where people work and how they are rewarded. Enterprises will need to adapt their policies on (older) employees' by organizing permanent education and training, and adapt their work environment to the capabilities and aspirations of their workers, including facilities for flexibility and variation in work schedules. Enterprises will also need to adapt their products, marketing and sales practices to the expanding pool of elderly consumers (see European Commission, Global Europe 2050, 2012). Widening the talent pool by activating and retaining older workers may become a strategic necessity. Enterprises need to understand this and actively and gradually prepare for retaining larger numbers of older workers. Despite the evident (see Council of Europe, Active Ageing, 2004), working longer years is still vehemently opposed by organizations such as trade unions, prospective pensioners, some political parties and enterprises. 


\section{European Human
Journal of Security}

Europe's demography reveals an ageing workforce and policy responses necessitate further feminization of the workforce (more women in work), working longer years, and attracting growing numbers of skilled migrant workers from developing countries.

After 2018, European economies may face considerable shortages in their labor supply. Shortages have already been seen in key sectors such as science, technology, engineering and healthcare (see, for example, European Parliament, Labor Market Shortages in the European Union, 2015).

Figure 4: Population prospects (working age 15-59) in selected regions in the world (United Nations Population Division, 2017)

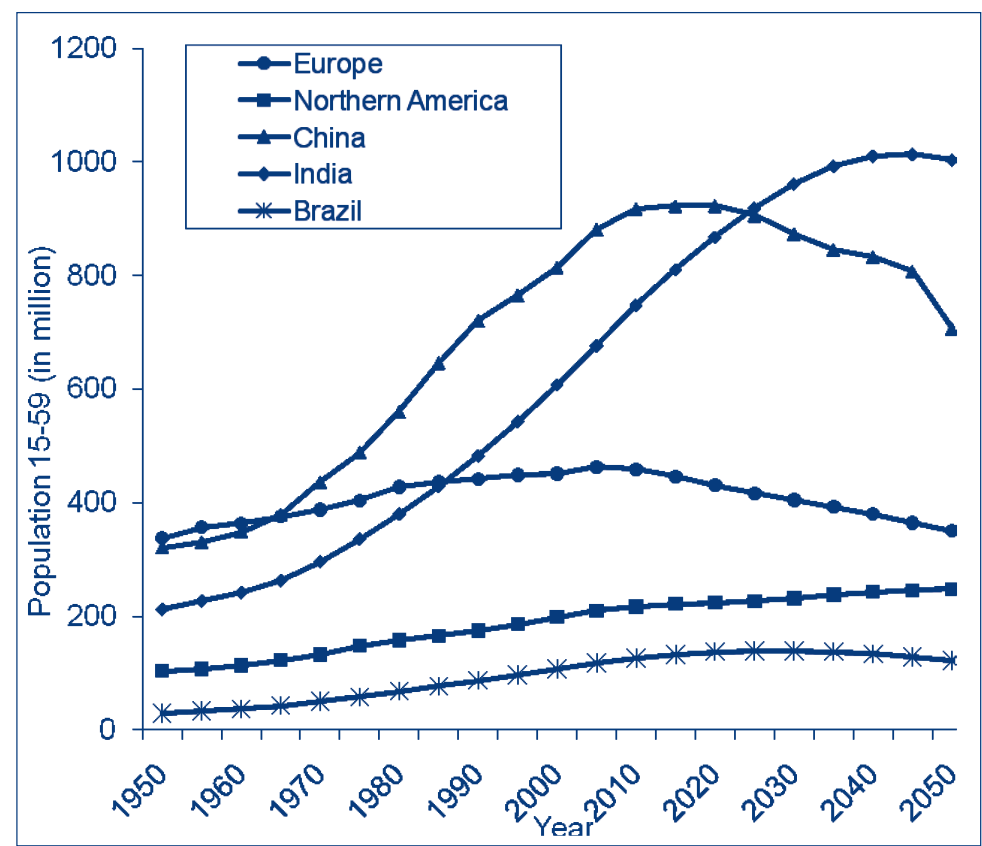

In Europe, in a longer-term prospective - up to the mid-21st century - demography will be an ever-stronger driver for change, with more jobs than people in an ageing landscape. Immigration is not a long-term solution to Europe's ageing workforce (migrants also age and have fewer children than in their country of origin), but a 
European policy on legal migration and integration is necessary in the context of both demography and global competition for attracting and retaining skills and talents.

When reflecting on the possible future, it is also necessary to think 'out of the box'. Social media are powerful tools for supporting debates on the possible future. ${ }^{5}$ The automation-driven changes may entail a possible shift towards post-work society where the need for adults to spend vast part of their lives at work will have been eliminated and work will have become optional people would work because it is fun. The non-addressed question remains as to how the pre-work ${ }^{6}$ developing countries could fend for themselves in the post-work world of the prosperous economies.

\section{Take-up of research findings for immigration policy implementation and policy changes}

In a forward looking European Commission study Global Europe 2050, economists advanced a plausible hypothesis that the EU-28 would need one million recruited immigrants per year between 2030 and 2050 . They would be aged 20 to 45 and coming from Third Countries. What economic models often underestimate is the overall population dynamics. Recruiting one million worker-immigrants aged 20 to 45 per year between 2030 and 2050 would (due to family formation and family reunification) result in a minimum of 62 million new citizens with an immigrant background in 2050 (estimation by Avramov for Global Europe 2050). Is that too many foreigners?

5 The notions of expected, probable and possible future were developed by the French family sociologist and demographer Louis Roussel in his masterpiece "La Famille incertaine" (1989).

6 Here we refer to 'work' as we know it in the developed countries with regulated employment and working conditions, limited number of working hours per week and days per year, fringe benefits, low retirement age and work-based pensions. 


\section{European Human}

It is reasonable to assume that the general population would need to accept and provide favorable conditions for inclusion for such large numbers of foreigners in the labor market, education, housing, and eventually retirement schemes, just to name a few. One of the requirements is that immigrants are welcome. So let us look at what has been known in academia for 10 years or so about the acceptance of immigrants in Europe. First, we have known for years that in the EU there is an East/West divide in (not) welcoming immigrants. At the turn of the century, two-thirds of nationals in Poland, the Czech Republic, Hungary, Slovenia, Germany and Estonia were already of the opinion that there are too many immigrants in their country. The share of foreigners at the end of the 20th century was 0.1 percent in Poland, 2 percent in the Czech Republic, Hungary, and Slovenia, 8 percent in Germany and 26 percent in Estonia (Avramov, 2008).

Despite small numbers and low shares of immigrants, as many as 40 percent in Hungary agreed that there is no room for foreigners in their country in the 2000s. The study revealed that the actual number of foreigners does not appear to impact the opinion that there are already too many foreigners in any of the eight countries under consideration (European Commission, Global Europe 2050, 2012).

A significant share of Hungarians shared the sentiment that immigration is a threat and expressed this anti-immigration sentiment 15 to 20 years ago. Policymakers had more than a decade to contribute to changing the population climate with respect to migrants and immigration issues, had they wanted to. Events in recent years seem to indicate that they did not want to. It should come as no surprise that the transit along the Balkan route of a significant number of people originating mostly from Muslim-majority countries such as Syria, Afghanistan and Iraq reignited the simmering non-acceptance of immigrants in Hungary. Current policy choices are embedded in this popular sentiment. 
The European Union has been funding research and technological development since 1984 under the EC Framework Programmes. Research and innovation projects are meant to be support to European policy. International migration has been considered as a fundamental issue of politics and policy.

Page I 50 There is no comprehensive EU inventory of all the research projects, coordinated actions, networks of excellenceand peer-learningactivities that have provided research findings and drawn policy implications, recommendations, guidelines, and inventories of 'best practice' on how to manage immigration. An informed hypothesis is that there have been hundreds. We will use one as an example to illustrate the timeline between knowledge and events that trigger crises.

In 2005, the EC funded the research project Needs for Female Immigrants and Their Integration in Ageing Societies (FEMAGE, 2005-2007). The timeliness of the study about the challenges for Europe's demographic future and social cohesion, which are associated with the immigration flows and the presence of thirdcountry nationals in the European Union, could not be overestimated. The European Commission was going to unveil its plan for a Blue Card for skilled immigrants that would have allowed suitably qualified people and their families to live and work within the European Union. One of the outputs of the FEMAGE project was the book Acceptance of Immigrants in Europe? (Avramov, 2008). The analysis built on the national Population Policy Acceptance Surveys (PPAS) and the international database FEMAGE-MIG (Avramov \& Cliquet, 2007), capturing the viewpoints about immigration and expectations towards foreigners in the Czech Republic, Germany, Estonia, Hungary, Austria, Poland, Slovenia and Finland. However, the timeliness, relevance and pertinence of the research findings did not enhance the policy impact of the study. There was no significant take-up of the research findings of this project funded by the EC. The research findings were largely ignored and were not taken up for policy building by Member 


\section{European Human}

States, or the EC for that matter. In policy circles, there was no obvious need for reconciling long-term needs for immigrants with the widespread prejudices embedded in fears of loss of work to foreigners and acculturation by foreigners.

The publication of the book conveying a message that large segments of the population are not willing to accept immigrants in countries such as Hungary, Poland and the Czech Republic and the official rejection by Hungary and Poland to accept the relocation of any refugees from Greece and Italy and the acceptance of 12 people by the Czech Republic took place some fifteen years apart. At best, nobody bothered to change the population climate in these countries; at worst, groups drew their political capital from fears about foreigners. As a consequence of the dismissal or the choice to ignore the research findings, the European 2015 scheme for relocation and resettlement ${ }^{7}$ remains a statistical exercise and has not become an effective tool for supporting human security.

We acknowledge that in the Social Sciences and Humanities (SSH) in general, and in migration research in particular, theories, methods and data matter and research may produce different results. Researchers are not ideology-free and may draw different policy conclusions and recommendations based on similar research findings (IMPACT-EV, 2014). This may make policymakers nervous and reluctant to consider research evidence.

We need great caution for assessing policy and social implications of research on migration issues, but one takeaway is relevant: EU policy agendas on immigration and security may need to add actions to shape attitudes and expectations of natives and immigrants in realistic directions in order to enable and improve integration capacities of Member States.

7 See: https: //ec.europa.eu / home - affairs / sites / homeaffairs /files/what-we-do/policies/european-agenda-migration/ background-information/docs/communication_on_the_ european_agenda_on_migration_annex_en.pdf 
Transition countries, such as those along the Balkan route, including Serbia, may expect to have to provide more than temporary shelter/parking for people escaping war and/or poverty. In that respect, preparing the population to actually integrate some refugees and relocated asylum seekers, especially those having the needed skills, may be a wise policy choice. Western Balkan countries are less prosperous than Austria, Germany, or Sweden, the preferred destinations for migrants, but are more prosperous than many countries from which refugees and asylum seekers originate.

\section{Is the presence of large numbers of immigrants inevitably a problem?}

There is plenty of evidence that Europe has managed immigration badly. Narratives about tolerance (often used as a tool for hidden segregation), multiculturalism (often used as a tool for hindering the social mobility of certain groups), the right to work for illegal immigrants (often used as a tool to dismantle European social security systems), denials such as "there is no such thing as immigrant background" (we have all come from somewhere and are now all citizens) and "there is no such thing as integration" (who is integrated?), just to mention some ideology-loaded notions and lobbying platforms, were not particularly helpful.

Ideological bias in multicultural /communitarianism/ integration narratives in the SSH focusing only, or predominantly, on the structural integration of immigrants and insufficiently addressing the controversy between ideology of communitarianism and values of modernity (see, for example, Avramov \& Cliquet, 2005; Cliquet \& Avramov, 2017) needs to assume part of the responsibility for the mismanagement of immigration.

Nevertheless, it may be concluded that the mismanagement of migration in Europe is not an outcome of bad research or lack of robust research-based evidence. The mismanagement of immigration and effective integration of immigrants may be the outcome of bad policy choices 


\section{European Human}

partly due to the low take-up or extremely selective use of fragmented knowledge from research.

The population of countries such as Hungary, Poland, or the Czech Republic may think that there are too many foreigners but are there too many immigrants in Switzerland - a country with one of the highest shares of immigrants in Europe. In the Swiss Confederation, with three main languages and three cultural communities, resident foreigners and temporary workers make up about 22 percent of the population. ${ }^{8}$ An average of 40,000 foreigners have naturalized each year since 2002. It may be assessed that some 30 percent of its population is with immigration background. ${ }^{9}$

Evidently, when discussing the Swiss numbers, we need to address the composition of the immigrant groups, specific characteristics of the immigrants, and the effectiveness of the economic, social and cultural integration policies and practices of the host country.

Nevertheless, the evidence from Switzerland points in the direction of the conclusion that it is not (only) about numbers. It is more so about the integration of immigrants. This leads us to conclude that forwardlooking in terms of numbers of immigrants wanting to come to Europe, and/or being needed by European economies, needs to be looked at in terms of integration capacities of the European host countries, and the EU as a whole, and not only in terms of labour force statistics.

\section{Forward-looking strategies on integration and human security}

Immigration and human security discourse needs to be broadened to include structures and processes to enhance capacities for the comprehensive inclusion of immigrants in society.

8 See: http://www.migrationpolicy.org/article/switzerlandsnon-eu-immigrants-their-integration-and-swiss-attitudes

9 See, for example: https://data.oecd.org/migration/foreignborn-population.htm

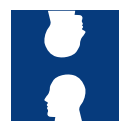


Research has shown that an analytical approach proposed by Heckmann (2000) for addressing integration is still relevant and useful. He suggests the following kinds and degrees of integration of immigrants. Structural integration entails the acquisition of rights and access to positions and statuses in the core institutions of the receiving society by the immigrants and their descendants. Cultural integration encompasses processes of cognitive, cultural, behavioral and attitudinal change in individuals. Social integration relates to people's private relations, group and associational membership. Identificational integration concerns membership in a new society and is shown in feelings of belonging and identification (Heckmann, 2000).

One of the pre-requirements for successful integration is embedded in the population climate in the receiving countries. Going back to the FEMAGE study, we can illustrate some key expectations of natives towards foreigners and integration. We see that people attach much importance to cultural integration. The vast majority of people, 85 percent of Hungarians and 59 percent of Western Germans, shared the view that foreigners should master the language and abide by the customs and rules of the host country. They also shared the view that immigrants who have not integrated after five years should return to their own country.

It is easy to label large shares of a population as xenophobes, but the expectations towards foreigners are in line with the notion of citizenship - all citizens are expected to abide by the customs and rules of the country. Indeed, in all eight countries the overwhelming majority of natives expected foreigners to make the effort to adapt to the core cultural norms of the host country.

Not much seems to have changed regarding the population climate in recent years. What has changed over the past 15 years or so is that the numbers of foreign-born have been increasing in many EU countries, but more importantly that diversity has been increasing in terms of native languages, religions, and phenotypic 


\section{European Human}

characteristics. This diversity inevitably entails changes in the narratives about integration, ethics and cultural norm hierarchies. ${ }^{10}$

\section{Capacity for integration and security}

What we are suggesting is that the integration scenarios need to be the basis for the appraisal of needs for immigrants according to different sectors of economy and educational attainment, age and family situation. These reflections also need to take into account the hidden potential for activating the already present stock of immigrants and people with foreign origin. They also need to take into account the prospects of competition at the bottom segment of the labor market between autochthones and all others but also between newly arriving immigrants and immigrants already settled in the destination country.

In fact, what we are suggesting is to explore the feasibility, in the European context, of practices of countries like the USA, Canada, Australia, New Zealand countries that have been praised for their integration of immigrants, often withoutacknowledging thatimmigrants are being selected/pruned and 'cherry-picked' according to desired personal and family characteristics.

What we are suggesting is that discussions about 'needs for immigrants' based on crunching numbers are unproductive and that the key challenge for the social sciences and humanities is to open and address issues of requirements for enhancing the integration capacity of different countries. Human security as freedom from want and freedom from fear (UNDP, 1994) needs to include freedom from fear of foreigners and conflicts between communities.

Community-based recruiting practices such as bilateral agreements for recruiting workers, as was the case in Belgium for attracting Italians in the second half

10 We are here referring to hierarchy or norms and not hierarchy or cultures. 
of the 1940s (see the Bilateral Agreement Italy-Belgium, $1946^{11}$ ) or Moroccans in the mid-1960s (see, for example, the February 1964 bilateral labor force agreement; and Bousetta (2008) discussion about the resulting migration flows), have not been glorious examples of good practices. One can assume that individual skills and talents, rather than countries of origin, as basis for recruitment practices are more conducive to inclusion in the host country.

In the context of forward-looking, we could revisit, in some other article, the Global Europe 2050 assumption that Europe needs to have a net inflow of one million immigrants per year over the next few decades in the light of the 'capacity to integrate' scenarios and more specific skills of needed workers.

\section{Global, national, regional, and communal levels of integration}

Management of immigration and integration of immigrants is obviously a European policy issue and a national issue. But in reality, the concentration of immigrants in particular regions (districts) has impacts at the local level, which may be more significant than those at the country level. The sense of belonging to one's own community and the forging of alternative systems of values and norms for guiding behavior towards others can also produce global impacts as may be seen from the example of Brussels. Brussels, with 62 percent of foreign-born residents, ranks second only to Dubai, which has 83 percent of foreign-born residents (World Migration Report 2015). Brussels is authentically multicultural as it has two official languages (French and Dutch) and a governance system that equally involves the two linguistic communities. In recent years, it is the municipality of Sint-Jans-Molenbeek (in Dutch, one of the official languages in Brussels) or Molenbeek-Saint-Jean

11 The agreement provides for the sending of 50,000 Italian workers (2,000 per week) into the Belgian mines in exchange for the right to get 200 kilos of coal per miner and per day paid by Italy (see the ROUTES project). 


\section{European Human}

(in French, also one of the official languages in Brussels) that has become known as an example of violent communitarianism that has produced fertile grounds for breeding, sheltering and protecting some notorious Muslim-inspired extremists and terrorists. Although it encompasses numerous immigrants, the municipality developed features and non-formal communitarian structures by its population originating predominantly from Morocco. Some 11 percent of the legally resident population has Moroccan nationality and 40 percent of all foreigners are Moroccan. ${ }^{12}$ Estimates about the share of Belgian nationals with Moroccan extraction living in Molenbeek are less reliable. As Albrecht Meier reported for Tagesspiegel, "the nature of immigration into Molenbeek has changed: in the beginning, in the sixties, people came here for work. Now, for many, Molenbeek is their destination merely because life here is easier than it is back in Morocco". ${ }^{13}$

The striking nature of violent communitarianism was exhibited when Salah Abdeslam, a Belgium-born French national of Moroccan descent, who was involved in the attacks in Paris on 13 November 2015, spent four months on the run and was hiding in Brussels. He was apprehended during a police raid conducted in the Molenbeek area of Brussels on 18 March 2016 - the area where he grew up. He was sheltered by his community in a house situated around the corner from where his parents and brother live. At the time of his arrest, the neighborhood youth was attacking the police trying to help Abdeslam to escape.

There is a burning need for the social sciences and humanities to contribute to human security by revisiting the notions and practices of communitarianism that pillarize and separate groups, and look at the degrees and types of integration that go deeper than the acquisition of the rights to work, housing, education, welfare protection, and include what Heckmann (2000) calls cultural, social and ideational integration.

12 See: http: // www.observatbru.be / documents / graphics / fiches-communales/2006/12_molenbeek-st-jean_fr.pdf

13 See: https://www.euractiv.com/section/security/interview/ molenbeek-mayor-poverty-is-no-excuse-for-radicalism

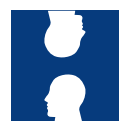




\section{Crisis management strategies and foresight}

A strategy for crisis management is being put in place by the European Union. It still appears to be a trial-anderror exercise. Calls for management of immigration in a longer-term perspective, such as action plans for reducing the incentives for irregular migration and developing a new policy on legal migration, are aspirational. The easy part of crisis management and border control is the use of 'off-the-shelf technology' available for managing borders, mobility, and creating a sense of in-group security.

Tracing effective pathways to achieving a new policy on legal migration is trickier. It may have to pass via reducing inequalities within countries, between generations, and between regions worldwide, and may require new toolboxes for fostering the structural, cultural, social and identificational integration of people who move between countries and regions of the world.

The question of excessive inequalities is too thorny an issue for Member States to allow EU institutions to tackle. This despite hundreds of EC-funded research projects that have demonstrated the negative effects of inequalities for individuals and for social cohesion, and numerous calculations of financial costs of inequality. The recent OECD publication "In It Together: Why Less Inequality Benefits All" (2015) is well taken up in narratives. The report provides an overview of inequality trends and policy directives. In terms of conclusions and its catchy title, it reiterates what has been known for a long time. However, the narrative about the negative impacts of excessive inequalities, or in the more policycorrect positive language, about the benefits of a lack of excessive inequalities, has not (yet) been taken up in policy implementation.

"Developing a new policy on legal migration: in view of the future demographic challenges the EU is facing, the new policy needs to focus on attracting workers that the EU economy needs, particularly by facilitating entry 


\section{European Human}

and the recognition of qualifications" 14 may need to pass via some pragmatic and unpopular roads entailing scouting for immigrants and screening of applicant immigrants according to the needs of different sectors of economy and immigrants' features (e.g. education, age, family situation, knowledge of the core values and norms enshrined in the EU and national legislations and administrative practices and willingness to accept them), the calculation of benefits and costs of recruiting immigrants in a longer-term perspective, consideration for effects at EU and also at national and local level, and elaboration of comprehensive integration scenarios and roadmaps. Calls for such a comprehensive approach may make politicians nervous and many lobbyists furious, but may be necessary for developing the integration capacity of different countries and localities and authentically enhancing human security.

14 See: https: // ec.europa.eu / home-affairs / what-we-do /policies / european - agenda - migration_en 


\section{REFERENCES}

Avramov, D. (Ed.). (2008). Acceptance of immigrants in Europe? Berlin: Pro Business Verlag.

Avramov, D., \& Cliquet, R. (2005). Integrated policies on gender relations, ageing and migration in Europe: Lessons from the Network for Integrated European Population Studies (NIEPS). Antwerpen: Garant.

Avramov, D., \& Cliquet, R. (2007). Manual, questionnaires, codebooks and databases of the FEMAGE study: Needs for female immigrants and their integration in ageing societies. Brussels: Population and Social Policy Consultants (PSPC).

Avramov, D., \& Cliquet, R. (2007). Xenophobia and integration of immigrants. Zeitschrift für Bevölkerungswissenschaft 32(3-4), 533-560.

Bilateral Agreement Italy-Belgium (1946), Agreement between Italy and Belgium concerning the recruitment of Italian workforce and their settling in Belgium, 1946 ROUTES project funded by the EC Education and Culture DG under Lifelong Learning Programme, http://routes.pixel-online. org/document 2931.html?id_doc $=57 \&$ str search_langreview $=\&$ str_search $=\&$ str_search_ wtype $=$ law\&doc_lang $=\&$ part_id $=14$

Bousetta, H. (2008). New Moroccan migrants in Belgium. Journal of Immigration \& Refugee Studies 6(3), 397-408.

Avramov, D., \& Cliquet, R. (2017). Evolution Science and Ethics in the Third Millennium [in press]. Springer.

Council of Europe (2016), Perspectives on Youth - Healthy Europe: confidence and uncertainty for young people in contemporary Europe. Youth Partnership: and European Union and Council of Europe. Council of Europe publishing. 


\section{European Human}

European Commission (2015) Final Communication from the Commission to the European Parliament, the Council, the European Economic and Social Committee and the Committee of the Regions a European Agenda on Migration.European Commission, Brussels.

European Commission (2012), Global Europe 2050. Directorate-General for Research and Innovation Directorate B - European Research Area Unit B.5. Social Sciences and Humanities, Brussels.

Ewing, B. et al.(2010). Ecological footprint atlas 2010. Oakland, CA: Global Footprint Network.

Heckmann, F. (2000). Integration research in a European perspective. Proceedings from the First Workshop on Demographic and Cultural Specificity and Integration of Migrants. Brussels: NIEPS, Centrum voor Bevolkings-en Gezinsstudies (CBGS).

IMPACT-EV Evaluating the impact of outcomes of EU SSH research (2014),State of the artin the scientific, policy and social impact of SSH research and its evaluation. Reale, Primeri (CNR-CERIS), Flecha, Soler, Oliver, Puigvert (UB-CREA), Sordé (UAB), Schubert, Soòs, Mosoni-Fried (MAGYAR TUDOMANYOS AK), Canhilal, Lepori (USI), Avramov (PSPC), Holm, Travis (TCD), Larkin (UCardiff), Scharnhorst, Hogenaar, Van Horik (KNAW-DANS), Donovan (BU). http://impact-ev.eu/

International Organization for Migration (2015), World Migration Report 2015. IOM, Geneva

OECD (2015), In It Together: Why Less Inequality Benefits All. OECD, Paris.

Roussel, L. (1989). La famille incertaine. Paris: Odile Jacob.

UNDP (1994), Human Development Report 1994. Oxford University Press, New York.

United Nations Population Division(2017), World Population Prospects 2017. United Nations, New York.

Wackernage, M., \& Rees, W. (1996). Our ecological footprint: Reducing human impact on the earth. Gabriola Island, BC: New Society Publishers. 